\title{
Bahan Ajar Tema Daerah Tempat Tinggalku Berbasis Kearifan Lokal
}

\author{
Aldine Pramita Alba ${ }^{1}, \mathrm{Sa}^{\text {'dun }} \mathrm{Akbar}^{2,}$ Nurchasanah $^{3}$ \\ ${ }^{1}$ Pendidikan Dasar-Universitas Negeri Malang \\ ${ }^{2}$ KSDP-Universitas Negeri Malang \\ ${ }^{3}$ Pendidikan Bahasa Indonesia-Universitas Negeri Malang
}

\section{INFO ARTIKEL}

\section{Riwayat Artikel:}

Diterima: 01-03-2019

Disetujui: 15-04-2019

\section{Kata kunci:}

teaching materials;

local wisdom;

bahan ajar;

kearifan lokal

\author{
Alamat Korespondensi: \\ Aldine Paramita Alba \\ Pendidikan Dasar \\ Universitas Negeri Malang \\ Jalan Semarang 5 Malang \\ E-mail: aldineparamita@gmail.com
}

Pendidikan merupakan salah satu komponen yang berfungsi untuk mencerdaskan generasi penerus bangsa. Salah satu tujuan pendidikan adalah menghasilkan siswa yang bersemangat untuk terus belajar, semangat untuk menambah ilmu pengetahuan, dan senantiasa memiliki rasa ingin tahu yang tinggi sehingga proses belajar diharapkan tidak hanya terjadi pada pendidikan formal tapi berlangsung seumur hidup (Arief, 2016). Proses belajar yang terjadi pada setiap peserta didik juga berbeda-beda. Berfokus pada prinsip bahwa belajar adalah proses yang aktif dan konstruktif, penelitian telah menyelidiki cara-cara dimana peserta didik dapat mengendalikan proses belajar mereka sendiri (Nugraha, 2016). Selain berfungsi untuk mencerdaskan generasi bangsa, pendidikan juga berpengaruh terhadap pembentukan karakter pada diri siswa. Dengan pendidikan, karakter setiap individu akan terbentuk (Ulya, 2016). Pendidikan karakter pada anak sebaiknya diterapkan mulai usia anak sekolah dasar.

Sekolah Dasar merupakan fondasi awal dalam jenjang pendidikan yang akan memengaruhi pendidikan dalam jenjang yang lebih tinggi. Sekolah merupakan bagian dari pendidikan yang merupakan salah satu tempat untuk mengembangkan kemmapuan prestasi siswa (Siahaan, 2018). Pendidikan dasar juga menyebabkan perubahan dalam diri siswa. Pnegetahuan telah menjadi faktor produksi yang unggul dan ia membutuhkan manajemen yang sangat hati-hati dan sadar seperti terbentuknya teman secara alami (Kluge, 2001). Hal yang menunjang tercapainya perubahan kognitif, afektif, dan psikomotorik siswa ke arah yang lebih baik adalah keselarasan antara penilaian, pembelajaran, dan proses pembelajaran. Penilaian, pembelajaran, dan proses pembelajaran saling terkait dan saling memberikan informasi untuk penyesuaian (Harsiati, 2017).

Pada era sekarang, pendidikan menganut kurikulum 2013. Kurikulum 2013 telah mempermudah guru dalam melaksanakan proses belajar mengajar. Salah satu cara dalam mempermudah guru yaitu dengan ketersediaan buku guru dan buku siswa. Pada buku siswa juga tersedia penyampaian materi yang berupa permainan. Jelas, aturan permainan memiliki fungsi memberi tahu pemain cara bermain game, yaitu tindakan mana yang diizinkan untuk diambil, bagaimana materi game ditempatkan, menentukan kapan game berakhir dan kondisi kemenangan mana yang ada (Liebe, 2008).

Pengembangan bahan ajar tematik berbasis kearifan lokal dikembangkan dengan tujuan memecahkan salah satu masalah yang ada di sekolah. Masalah yang dimaksudkan tersebut adalah kurangnya ketersediaan bahan ajar yang sesuai dengan karakteristik lingkungan sekolah. Pengembangan bahan ajar sesuai dengan karakteristik sekolah ini tentunya mengacu pada tuntutan kurikulum yang sedang diterapkan di sekolah. Buku ajar merupakan buku teks yang digunakan sebagai rujukan standar pada mata pelajaran tertentu dalam kegiatan pembelajaran (Akbar, 2013). Berbeda dengan yang diungkapkan Prastowo 
(2014), buku ajar meupakan buku yang berisi ilmu pengetahuan yang diturunkan dari kompetensi dasar yang terdapat dalam kurikulum dan digunakan oleh siswa.

Berangkat dari permasalahan di lapangan dari hasil kajian lebih lanjut peneliti akan mengembangkan bahan ajar berbasis kearifan lokal yang ada di daerah tempat siswa belajar, yaitu daerah Malang. Proses pembelajaran yang dilaksanakan tidak harus selalu secara berkelompok maupun individu, namun ada kombinasi diantara keduanya. Pada saat peneliti melakukan studi pendahuluan, peneliti menemukan berbagai masalah. Salah satu masalah yang dimaksud tersebut ialah, siswa kurang tertarik dengan buku tematik karena terlalu banyak materi yang harus dipelajari dan minim akan gambar. Oleh karena itu, solusi untuk pengembangan bahan ajar ini sangat cocok untuk dilakukan karena dalam pengembangan bahan ajar ini akan didesain sesuai dengan karakteristik siswa sekolah dasar yang menyukai ketersediaannya gambar-gambar untuk menunjang pengetahuan siswa sesuai dengan materi yang sedang dipelajari.

\section{METODE}

Penelitian ini termasuk ke dalam penelian dan pengembangan karena penelitian ini mengasilkan produk dari hasil pengembangan berupa bahan ajar berbasis kearifan lokal. Penelitian ini menggunakan model pengembangan Dick \& Carey dengan mengacu sampai sembilan langkah pengembangan saja. Hal ini dikarenakan, penelitian ini berfokus pada pengembangan bahan ajar. Model pengembangan Dick \& Carey terdiri atas; (1) analisis kebutuhan untuk menentukan tujuan pembelajaran; (2) melakukan analisis pembelajaran dan keterampilan; (3) mengalaisis siswa dan lingkungan; (4) merumuskan tujuan khusus; (5) mengembangkan instrumen penilaian; (6) mengembangkan strategi pembelajaran; (7) mengembangkan dan memilih materi pembelajaran; (8) merancang dan melakukan evaluasi formatif; (9) merevisi pengajaran.

Pada tahap identifikasi tujuan umum, peneliti melakukan empat kegiatan terdiri atas; (a) studi pustaka, (b) studi pendahuluan/lapangan, (c) identifikasi masalah, dan (d) identifikasi kebutuhan. Studi pustaka dilakukan dengan tujuan untuk menemukan konsep dan landasan teori berkaitan dengan produk yang akan dikembangkan. Identifikasi pendahuluan/lapangan dilakukan dengan tujuan melihat kegiatan pembelajaran beserta perangkat pembelajaran yang digunakan dalam kegiatan pembelajaran. Kemudian, peneliti melakukan identifikasi masalah yang berangkat dari hasil identifikasi pendahuluan sehingga peneliti mengetahui karakteristik yang tepat untuk digunakan dalam pembelajaran sesuai dengan kondisi siswa. Kegiatan terakhir pada langkah ini yaitu identifikasi kebutuhan, disini peneliti menyimpulkan bahwa dibutuhkan buku ajar yang sesuai dengan karakteristik dan kondisi pada lingkungan sekolah dengan berbasis kearifan lokal daerah setempat.

Pada tahap analisis pembelajaran dan keterampilan, peneliti melakukan analisis pembelajaran dengan mengidentifikasi kemampuan siswa yang terdiri dari kemampuan afektif, kognitif, dan psikomotorik untuk mencapai tujuan umum yang sudah ditentukan. Pada tahap menganalisis karakteristik siswa dan konteks pembelajaran peneliti menggali bakar, motivasi, gaya belajar dan kemampuan awal peserta didik menggunakan teknik observasi. Tahap keempat, yaitu merumuskan tujuan khusus pembelajaran dilakukan dengan menguraikan indikator menjadi tujuan pembelajaran dan kegiatan pembelajaran yang spesifik. Kegiatan ini dilakukan dengan berpatokan pada aspek audience, behaviour, conditions, and degree (ABCD). Tahap selanjutnya yaitu mengembangkan instrumen penilaian, tahap ini dilakukan dengan merumuskan soal-soal tes yang digunakan dalam proses evaluasi pada kegiatan pembelajaran. Tahap keenam, yaitu mengembangkan strategi pembelajaran yang sesuai dengan karakteristik peserta didik. Tahap ketujuh yaitu mengembangkan bahan ajar tematik dilanjutkan tahap kedelapan yaitu merancang dan melakukan evaluasi formatif. Tahap merancang dan melakukan evaluasi formatif ini menghasilkan instrumen penilaian yang digunakan untuk mengumpulkan data. Proses dalam mendapatkan data ini melalui mendesain uji coba dan menetapkan subjek uji coba. Tahap kesembilan yaitu melakukan revisi pengajaran. Pada tahap ini peneliti melakukan pengulangan siklus pengembangan khsusnya pada perangkat pembelajaran. Revisi yang dilakukan berdasarkan hasil pelaksanaan pembelajara dari setiap tahap.

Data bahan ajar penelitian ini terdiri dari kelayakan yang memenuhi kriteria pada aspek validitas dan kepraktisan. Kepraktisan produk berfokus pada (a) kemenarikan tampilan bahan ajar, (b) keterbacaan isi/materi dan kemudahan penggunaan, dan (c) keunggulan basis kearifan lokal.

\section{HASIL DAN PEMBAHASAN}

Pada penelitian ini mencakup lima uji validasi, ahli materi, validasi ahli teknologi pembelajaran, uji coba perorangan, uji coba kelompok kecil, dan uji coba lapangan. Hasil analisis uji validasi ahli materi menunjukkan presentase 93,96\% memperoleh kriteria sangat valid dan dapat digunakan sehingga layak diimplementasikan. Uji validasi ahli teknologi pembelajaran memperoleh presentase sebesar 87,5\% mmperoleh kriteria valid dan dapat digunakan dengan revisi skala kecil, sehingga layak diimplementasikan. Sesuai dengan masukan yang diberikan validator bahan ajar ini akan tetap direvisi sesuai dengan masukan. Uji perseorangan yang dilaksanakan dengan melibatkan tiga siswa di SDN Purwantoro 8 Malang.

Hasil persentase yang diperoleh dari uji perseorang tersebut yaitu (1) persentase keterlaksanaan buku guru dan buku siswa 91,6\%, (2) kemanfaatan bahan ajar 89,7\%, dan (3) kemenarikan bahan ajar 81\%. Berdasarkan hasil persentase yang diperoleh dari uji perseorangan tersebut buku guru dan buku siswa dapat digunakan karena telah memenuhi syarat kevalidan. 
Uji kelompok kecil yang dilaksanakan pada enam siswa SDN Purwantoro 8 Malang. Pada uji kelompok kecil ini memperoleh persentase, yaitu (1) keterlaksanaan buku guru dan buku siswa sebesar 94,8\%, (2) kemanfaatan buku sebesar 95,5\%, dan (3) kemenarikan buku sebesar $81 \%$.

Keefektifan bahan ajar ini dapat dilihat berdasarkan hasil belajar siswa sebelum menggunakan buku ajar dan setelah menggunakan buku ajar. Hasil uji lapangan di SDN Purwantoro 8 Malang dengan jumlah 25 siswa menunjukkan presentase keterlaksanaan buku guru dan buku siswa yaitu 96,04\%, kemanfaatan buku sebesar 95,86\% dan persentase kemenarikan sebesar $90 \%$. Hasil tersebut menunjukkan bahwa bahan ajar berbasis kearifan lokal Kota Malang sangat valid untuk digunakan. Secara umum, hasil analisis tingkat kevalidan buku guru dan buku siswa yang dikembangkan dapat dilihat pada tabel 1 .

Tabel 1. Hasil Analisis Tingkat Kevalidan Buku Guru dan Buku Siswa

\begin{tabular}{|c|c|c|c|c|}
\hline Produk yang Divalidasi & Validator & Persentase & Kriteria & Saran \\
\hline \multirow[t]{2}{*}{$\begin{array}{l}\text { Buku tematik guru dan siswa berbasis nilai- } \\
\text { nilai kearifan lokal Malang Raya subtema } \\
\text { keunikan daerah tempat tinggalku untuk } \\
\text { siswa SD kelas IV }\end{array}$} & $\begin{array}{l}\text { Ahli Teknologi } \\
\text { Pembelajaran }\end{array}$ & $87,5 \%$ & $\begin{array}{l}\text { Sangat valid atau } \\
\text { sangat baik untuk } \\
\text { digunakan }\end{array}$ & $\begin{array}{l}\text { 1. Pada buku guru hendaknya } \\
\text { tujuan pembelajaran } \\
\text { memperhatikan ABCD } \\
\text { 2. Ada beberapa gambar yang perlu } \\
\text { diberikan rujukan } \\
\text { 3. Secara keseluruhan sudah baik }\end{array}$ \\
\hline & Ahli Isi/ Materi & $92,8 \%$ & $\begin{array}{l}\text { Sangat valid atau } \\
\text { sangat baik untuk } \\
\text { digunakan }\end{array}$ & $\begin{array}{l}\text { 1. Buku guru tujuan pembelajaran } \\
\text { perlu ditinjauk kembali (ABCD) } \\
\text { 2. Kata dengan pada tujuan } \\
\text { pembelajaran lebih baik } \\
\text { digantikan dengan kata setelah, } \\
\text { melalui dst. } \\
\text { 3. Buku siswa sudah cukup baik } \\
\text { untuk tatanan tematik terpadu } \\
\text { 4. Untuk RPP waktu dibagi } \\
\text { menjadi tiga saja }\end{array}$ \\
\hline
\end{tabular}

\section{Sumber: Angket Validasi Ahli Tehnologi Pembelajaran dan Ahli Isi/ Materi}

Berdasarkan data pada tabel di atas dapat diketahui bahwa tingkat kevalidan buku guru dan buku siswa yang dikembangkan mencapai $97,5 \%$ dengan kriteria sangat valid sehingga dapat dipergunakan dalam pembelajaran. Meskipun produk yang dikembangkan telah memenuhi kriteria akan tetapi masih terdapat beberapa saran/komentar dari validator untuk perbaikan yang lebih baik lagi terhadap produk yang dikembangkan. Untuk itu, peneliti tetap melakukan peninjauan kembali dan revisi dalam menyempurnakan kekurangan-kekurangan yang terdapat dalam buku guru dan buku siswa sesuai saran/komentar dari validator. Berdasarkan saran yang telah diuraikan pada Tabel 2 diketahui bahwa buku guru dan buku siswa sebaiknya diperbaiki dalam hal (1) tujuan pembelajaran; (2) sumber gambar; (3) alokasi waktu dalam RPP. Maka peneliti akan melakukan perbaikan sesuai dengan saran dan komentar ahli.

Data uji coba skala perorangan meliputi keterlaksanaan, kemanfaatan dan kemenarikan pada buku guru dan buku siswa berbasis nilai-nilai kearifan lokal subtema keunikan daerah tempat tinggalku. Data secara umum pelaksanaan uji coba skala perorangan, dapat dilihat pada gambar 1 .

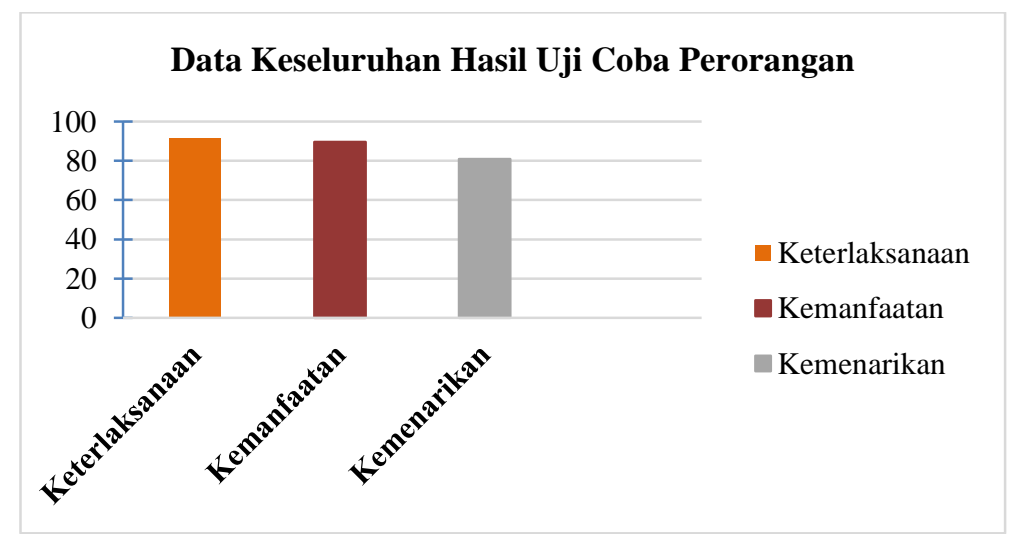

Gambar 1. Hasil Uji Coba Skala Perorangan 
Adapun beberapa data yang diperoleh dari pelaksanaan uji perorangan menghasilkan data, persentase keterlaksanaan buku guru dan buku siswa sebesar 91,6\%, kebermanfaatan sebesar 89,7\% dan persentase kemenarikan sebesar $81 \%$. Berdasarkan hasil belajar pada pelaksanaan uji coba perorangan dapat disimpulkan bahwa buku guru dan buku siswa yang dikembangkan dapat digunakan karena telah memenuhi kriteria sangat valid/sangat efektif, namun peneliti tetap melakukan revisi sesuai dengan saran dan komentar guru kelas.

Data uji coba skala kelompok kecil, meliputi keterlaksanaan, kemanfaatan, dan kemenarikan pada buku guru dan buku siswa berbasis nilai-nilai kearifan lokal subtema keunikan daerah tempat tinggalku. Data secara umum pelaksanaan uji coba skala kelompok kecil, dapat dilihat pada gambar 2.

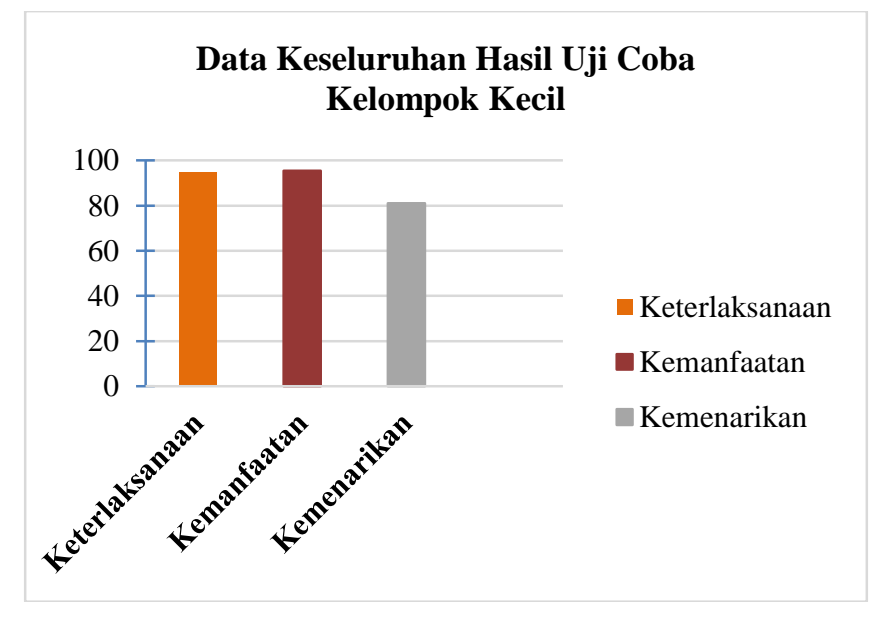

Gambar 2. Hasil Uji Coba Skala Kecil

Adapun beberapa data yang diperoleh dari pelaksanaan uji kelompok kecil menghasilkan data, persentase keterlaksanaan buku guru dan buku siswa sebesar 94,8\%, kemanfaatan sebesar 95,5\% dan persentase kemenarikan sebesar $81 \%$. Berdasarkan hasil belajar pada pelaksanaan uji coba perorangan dapat disimpulkan bahwa buku guru dan buku siswa yang dikembangkan dapat digunakan karena telah memenuhi kriteria sangat valid/sangat efektif, namun peneliti tetap melakukan revisi sesuai dengan saran dan komentar guru kelas.

Data uji coba skala lapangan meliputi keterlaksanaan, kemanfaatan, dan kemenarikan pada buku guru dan buku siswa berbasis nilai-nilai kearifan lokal subtema keunikan daerah tempat tinggalku yang dilaksanakan selama lima hari. Data secara umum pelaksanaan uji coba skala lapangan, dapat dilihat pada gambar 3 .

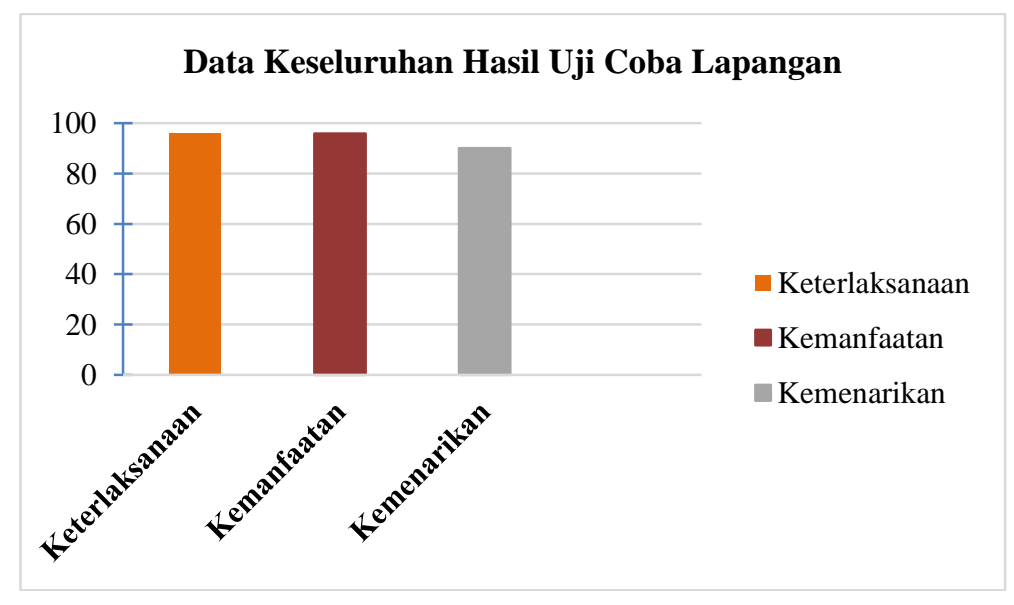

Gambar 3. Hasil Uji Coba Lapangan

Adapun beberapa data yang diperoleh dari pelaksanaan uji lapangan menghasilkan data, persentase keterlaksanaan buku guru dan buku siswa sebesar 96,04\%, kemanfaatan sebesar 95,86\% dan persentase kemenarikan sebesar 90\%. Berdasarkan hasil belajar pada pelaksanaan uji coba perorangan guru dan buku siswa yang dikembangkan dapat digunakan karena telah memenuhi kriteria sangat sangat efektif. 


\section{Materi/isi Produk Modul}

Peneliti mbermaksud mengembangkan bahan ajar berbasis kearifan lokal kota Malang. Kearifan lokal kota Malang sangat luas sehingga pengembangan bahan ajar ini menggunakan batasan-batasan, batasnya yaitu KD pada subtema I lingkungan tempat tinggalku yaitu cerita rakyat yang ada di kota Malang. Pengembangan bahasn ajar hasil dari perpaduan materi yang sudah diintregasikan dengan kearifan lokal yang ada di kota Malang. Bahan ajar ini membahas sejarah singosari, tari topeng malangan, asal mula Malang, dan keripik tempe sanan Malang. Kelima muatan pelajaran diintegrasikan dengan nilai-nilai kearifan lokal. Buku untuk kedalaman wawasan teoritis dan rekomendasi membuat dia mengetahui bahwa guru harus belajar bagaimana untuk mendengarkan anak-anak di kelas mereka karena mereka memiliki hak untuk didengar dan membutuhkan kompetensi yang terlibat dalam pendapat mereka (Bellous, 2007).

\section{Bahasa Produk Modul}

Dikaji dari hasil validasi para ahli didpati menggunakan bahasa yng diterapkan pada bahan ajar memenuhi aturan pengembangan bahan ajar dan dapat digunakan. Kemunculan sebuah kata berbobot relatif terhadap informasi tumpang tindih antara konteks saat ini dan sebelumnya konteks dimana hal itu terjadi. Ini yang membuat ukuran dinamis: nilai untuk dokumen tertentu tergantung pada caranya banyak informasi baru yang disumbangkannya tentang kata apa yang sebelumnya ditemui (Johns, 2016).

\section{Desain Produk Modul}

Desain produk dalam bahan ajar yang dikembangkan mengkaji dari erbagai macam kebudayaan kota Malang sehingga lebih terlihat ciri khas dari bahan ajar ini.

\section{SIMPULAN}

Bahan ajar berbasis kearifan lokal Kota Malang fokus keunikan daerah tempat tinggalku telah memenuhi unsur valid, efektif, manfaat, dan menarik sehingga boleh digunakan. Bahan ajar ini diharapkan tidak hanya dimanfaatkan untuk siswa kelas IV di SDN Purwantoro 8 Kota Malang, melainkan juga dapat digunakan sebagai buku penunjang seluruh siswa kelas IV sekolah dasar yang ada di kota Malang.

\section{DAFTAR RUJUKAN}

Arief, H. S., Maulana., \& Sudin, A. (2016). Meningkatkan Motivasi Belajar melalui Pendekatan Problem-Based Learning (PBL). Jurnal Pena Ilmiah, 1(1), 141-150.

Azizahwati., Maaruf, Z., Yassin, R. M., \& Yuliani, E. (2015). Pengembangan Modul Pembelajaran Fisika SMA Berbasis Kearifan Lokal untuk Meningkatkan Hasil Belajar Siswa. Makalah disajikan pada Prosiding Pertemuan Ilmiah XXIX HFI, Jateng \& DIY, 25 April 2015.

Bellous, J. E. (2008). How Children Become Moral Selves: Building Character and Promoting Citizenship in Education. Studies in Philosophy and Education, 28(2), 189-192. DOI 10.1007/s11217-008-9119-x.

Fityan, R.Y., \& Wahyudin, A. (2018). Keaktifan Sebagai Intervening dalam Pengaruh Perhatian, Kesiapan, Kemampuan Kognitif terhadap Hasil Belajar. Economic Education Analysis Journal, 7(1), 75—91.

Harsiati, T. (2017). Feedback and Self Regulation in Writing Learning Assesment in Junior High School. Journal of Intensive Studies on Language, Literature, Art, and Culture, 1(1), 71-85.

Indriani, A. (2013). Pengaruh Motivasi Belajar Siswa Kelas V terhadap Prestasi Belajar Matematika di SD Negeri Bejirejo Kecamatan Kunduran Kabupaten Blora. Jurnal Ilmu Pendidikan Matematika, 4(2), 134-139.

Istiyani, D. (2013). Model Pembelajaran Membaca Menulis Menghitung (CALISTUNG) pada Anak Usia Dini di Kabupaten Pekalongan. Jurnal Penelitian, 10(1), 1-18. DOI: https://doi.org/10.28918/jupe.v10i1.351

Johns, B., Dye, M., \& Jones, M. (2016). The Influence of Contextual Diversity on Word Learning. Psychon Bull Rev, 23, 1214-1220. DOI 10.3758/s13423-015-0980-7.

Kluge, J., Stein, W., \& Licht, T. (2001). Knowledge Unplugged. Germany: Mcinsey \& Company.

Liebe, M. (2008). There is no Magic Circle on the Difference between Computer Games and Traditional Games.

Conference Proceedings of the Philosophy of Computer Games 24-341. http://pub.ub.unipotsdam.de/volltexte/2008/2459/.

Nugraha, R. A., Degeng, N.S., \& Hanurrawan, F. (2016). Process of Self Regulated Learning an Stundent's Strategic Studies Activities in Learning Environment. International Conference on Education 2016. Education in the $21^{\text {th }}$ Century: Responding to Current Issues. 747-753.

Nurmanita, T., Harsiati, T., \& Suyono. (2017). Cerita Anak sebagai Sarana Pendidikan Karakter di Sekolah Dasar. Prosiding TEP \& PDs Transformasi Pendidikan Abad 21. Tema 7 Nomor 9 Bulan Mei Tahun 2017. 1100-1105.

Prastowo, A. (2014). Pengembangan Bahan Ajar Tematik. Jakarta: Kencana.

Puspita, H. J. (2016). Implementasi Pembelajaran Tematik Terpadu pada Kelas Vb SD Negeri Tegalrejo 1 Yogyakarta. Jurnal Pendidikan Guru Sekolah Dasar, 9(5), 884-893. 
426 Jurnal Pendidikan, Vol. 4, No. 4, Bln April, Thn 2019, Hal 421—426

Rizqi, A. M., Parmin., \& Nurhayati, S. (2013). Pengembangan Modul IPA Terpadu Berkarakter Tema Pemanasan Global untuk Siswa SMP/MTs. Unnes Science Education Journal, 2(1), 203-208.

Rozhana, K. M. (2015). Pengembangan Modul Berbasis Potensi Daerah Malang Kelas IV Semester II dengan Tema Tempat Tinggalku. Tesis tidak diterbitkan. Universitas Negeri Malang, Malang.

Sanjaya, W. (2013). Perencanaan \& Desain Sistem Pembelajaran. Jakarta: Kencana.

Setyowati, R., Parmin., \& Widiyatmoko., A. (2013). Pengembangan Modul IPA Berkarakter Peduli Lingkungan Tema Polusisebagai Bahan Ajar Siswa SMK N 11 Semarang. Unnes Science Education Journal, 2(2), $245-253$.

Siahaan, D. C., \& Pramusinto, H. (2018). Pengaruh Disiplin Belajar, Lingkungan Sekolah, dan Fasilitas Belajar terhadap Hasil Belajar. Economic Education Analysis Journal, 7(1), 279-285.

Ulya, F. L., Irawati, R., \& Maulana. (2016). Peningkatan Kemampuan Koneksi Matematis dan Motivasi Belajar Siswa Menggunakan Pendekatan Kontekstual. Jurnal Pena Ilmiah, 1(1), 121-130. 